\title{
Benextramine acts as an irreversible noncompetitive antagonist of U46619-mediated contraction of the rat small mesenteric artery
}

\author{
Pieter H. Van der Graaf ${ }^{1}$, Wiro B. Stam, Pramod R. Saxena * \\ Department of Pharmacology, Faculty of Medicine and Health Sciences, Erasmus University Rotterdam, P.O. Box 1738, 3000 DR Rotterdam, Netherlands
}

Received 4 January 1996; accepted 12 January 1996

\begin{abstract}
We have studied the effects of benextramine on the $\mathrm{U} 46619(11 \alpha, 9 \alpha$-epoxymethano-15S-hydroxy-prosta-5Z,13E-dienoic acid)-mediated contraction of the rat isolated small mesenteric artery. $\mathrm{U} 46619(10 \mathrm{nM}-10 \mu \mathrm{M})$ produced a concentration-dependent contraction of the small mesenteric artery. The selective prostanoid TP receptor antagonist, SQ $30,741 \quad([1 S$-[1 $\alpha, 2 \alpha(5 Z), 3 \alpha, 4 \alpha]]-7$ [[[[[(oxaheptyl)amino]acetyl]amino]-methyl]-7-oxabicyclo[2.2.1]hept-2-yl]-5-heptenoic acid; $1 \mu \mathrm{M}$ ), produced a parallel, rightward shift of the $\mathrm{U} 46619$ curve with an associated $\mathrm{pA}_{2}$ value of $7.43 \pm 0.09$. Treatment of tissues with $100 \mu \mathrm{M}$ benextramine depressed the maximum response to U46619 in a time-dependent manner. However, neither SQ 30,741 (10 $\mu \mathrm{M})$ nor U46619 (10 $\mu \mathrm{M})$ incubation significantly protected against this effect. Thus, benextramine acts as an irreversible noncompetitive antagonist of U46619. The mechanism of this action is not yet clear.
\end{abstract}

Keywords: Benextramine; Prostanoid TP receptor; (Rat); Mesenteric artery, small; SQ 30,741; U46619

\section{Introduction}

The tetramine disulphide, benextramine, has previously been classified and employed as an irreversible competitive antagonist of $\alpha$-adrenoceptors (Melchiorre, 1981) and neuropeptide Y receptors (Tessel et al., 1993; Palea et al., 1995). In this study, we investigated the effects of benextramine on the response of the rat isolated small mesenteric artery to the 9,11-methanoepoxy analogue of prostaglandin $\mathrm{H}_{2}, \mathrm{U} 46619$, which is believed to mediate contraction of vascular smooth muscle via a selective action at prostanoid TP receptors (Coleman et al., 1994). We show that benextramine acts as an irreversible antagonist of U46619 in the small mesenteric artery via an, as yet unknown, nonsyntopic mechanism.

\footnotetext{
* Corresponding author. Tel.: + 31-10-4087537; fax: +31-10-4366839; e-mail: SAXENA@FARMA.FGG.EUR.NL.

${ }^{1}$ Present address: Department of Preclinical Research, Urology and Gastroenterology Section, Synthélabo Recherche (L.E.R.S.), B.P. 248,10 Rue des Carrières, 92504 Rueil-Malmaison Cedex, France.
}

\section{Materials and methods}

\subsection{Rat isolated small mesenteric artery preparation}

Male Wistar rats (225-350 g) were killed by cervical dislocation and the mesentery was removed and placed in ice-cold modified Krebs-Henseleit solution of the following composition (mM): $\mathrm{NaCl} 119.0, \mathrm{NaHCO}_{3} 25.0, \mathrm{KCl}$ 4.7, $\mathrm{KH}_{2} \mathrm{PO}_{4} 1.2, \mathrm{MgSO}_{4} 1.2$, glucose 5.5, $\mathrm{CaCl}_{2} 2.5$ and ethylenediaminetetra-acetic acid 0.026 . Four arterial trees were dissected from each mesenteric vascular bed and were cleared of surrounding adipose tissue. From each arterial tree, a $\sim 2 \mathrm{~mm}$ ring segment was mounted in a small vessel myograph (J.P. Trading, Aarhus, Denmark) with separated $6 \mathrm{ml}$ organ baths (thermostatically controlled at $37 \pm 0.5^{\circ} \mathrm{C}$, containing modified Krebs-Henseleit solution and continuously gassed with $95 \% \mathrm{O}_{2}$ and $5 \%$ $\mathrm{CO}_{2}$ ) as described by Mulvany and Halpern (1977). The endothelium was removed by gentle rubbing of the intimal surface with a scoured whisker from a cat (Wang et al., 1994). Tissue responses were measured continuously as changes in isometric tension and were displayed on potentiometric chart recorders. 


\subsection{Experimental protocol}

Following a $30 \mathrm{~min}$ stabilization period, the internal diameter of each vessel was set to a tension equivalent to 0.9 times the estimated diameter at $100 \mathrm{~mm} \mathrm{Hg}$ effective transmural pressure $\left(l_{100}: 183 \pm 7 \mu \mathrm{m}, n=43\right)$ according to the standard procedure of Mulvany and Halpern (1977). After a further $30 \mathrm{~min}$ stabilization period, a calibration contraction $(6.6 \pm 0.5 \mathrm{mN})$ was obtained to $30 \mu \mathrm{M} 5$-hydroxytryptamine $(5-\mathrm{HT})$ in each tissue and the absence of the endothelium was then confirmed by the lack of a response to $10 \mu \mathrm{M}$ of the muscarinic acetylcholine receptor agonist, 5-methylfurmethide.

In the first experiment, following a washout period of $15 \mathrm{~min}$, the tissues were incubated for $60 \mathrm{~min}$ with $3 \mu \mathrm{M}$ indomethacin to prevent synthesis of endogenous prostanoids and with $1 \mu \mathrm{M}$ SQ 30,741 or vehicle. Single U46619 concentration-effect ( $E /[\mathrm{A}]$ ) curves were then obtained by cumulative additions as third-log unit concentration increments. Effect was expressed as percentage of the calibration response to $30 \mu \mathrm{M} 5-\mathrm{HT}$.

In the second series of experiments, the tissues were exposed to $100 \mu \mathrm{M}$ benextramine or vehicle for 30,60 or $120 \mathrm{~min}$ and were subsequently washed for $30 \mathrm{~min}$ with ten solution changes. Following $60 \mathrm{~min}$ incubation with 3 $\mu \mathrm{M}$ indomethacin, $\mathrm{U} 46619 \mathrm{E} /[\mathrm{A}]$ curves were obtained as described above. It was also investigated whether SQ 30,741 or U46619 could protect against the antagonistic action of benextramine. For this purpose, the same protocol as described above was employed, but the tissues were incubated until a response plateau was achieved with 10 $\mu \mathrm{M}$ SQ 30,741 (30 min) or with $10 \mu \mathrm{M} \mathrm{U} 46619$, before exposing the tissue to benextramine $(100 \mu \mathrm{M}, 30 \mathrm{~min})$ without washing SQ 30,741 or U46619. Preliminary experiments had shown that incubation with SQ 30,741 or U46619 alone (i.e. not followed by benextramine treatment) had no significant effect on the U46619 $E /[\mathrm{A}]$ curve (data not shown).

\subsection{Compounds}

The following compounds, obtained from the sources mentioned, were used: $\left[\mathrm{Arg}^{8}\right]$ vasopressin (acetate salt), benextramine tetrahydrochloride, 5-hydroxytryptamine creatine sulphate (5-HT), indomethacin and U46619 (11 $\alpha, 9 \alpha$-epoxymethano-15S-hydroxy-prosta-5Z,13E-

dienoic acid): Sigma Chemical Company, Netherlands; 5-methylfurmethide iodide: Wellcome Research Laboratories, UK; SQ 30,741 ([1S-[1 $\alpha, 2 \alpha(5 Z), 3 \alpha, 4 \alpha]]-7-[[[[[(o x a-$ heptyl)amino]acetyl]amino]-methyl]-7-oxabicyclo[2.2.1]hept-2-yll-5-heptenoic acid): Bristol-Myers Squibb, Princeton, NJ, USA. Indomethacin and SQ 30,741 were dissolved in absolute ethanol. U46619 was dissolved initially in $20 \%$ ethanol to give a $1 \mathrm{mM}$ stock solution and subsequently diluted in distilled water. All other drugs were dissolved in distilled water.

\section{Results}

\subsection{Interaction between $U 46619$ and $S Q 30,741$}

U46619 (10 nM-10 $\mu \mathrm{M})$ produced a concentration-dependent contraction of the small mesenteric artery (Fig. 1) and the individual $E /[\mathrm{A}]$ curve data $(n=5)$ were fitted to the Hill equation (see Jenkinson et al., 1995) to provide estimates of midpoint location ( $\left.\mathrm{p}[\mathrm{A}]_{50}: 7.38 \pm 0.06\right)$, midpoint slope $\left(n_{\mathrm{H}}: 1.5 \pm 0.1\right)$ and upper asymptote $(\alpha: 107$ $\pm 6 \%)$. SQ $30,741(1 \mu \mathrm{M})$ produced a parallel rightward shift of the U46619 E/[A] curve without significantly changing the Hill slope or maximum response $\left(\mathrm{p}[\mathrm{A}]_{50}\right.$ : $\left.5.93 \pm 0.09 ; n_{\mathrm{H}}: 1.7 \pm 0.2 ; \alpha: 107 \pm 7 \% ; n=5\right)$ and $\mathrm{a}$ $\mathrm{pA}_{2}$ value of $7.43 \pm 0.09$ was estimated, indicative of an action at prostanoid TP receptors (see Schumacher et al., 1989; Ogletree and Allen, 1992).

\subsection{Effect of benextramine on the U46619-induced con- traction}

Treatment with $100 \mu \mathrm{M}$ benextramine for 30,60 or 120 min, followed by washout, depressed the maximum response to U46619 in a time-dependent manner (Fig. 2). In an attempt to clarify the mechanism behind this action, we investigated whether incubation with either SQ 30,741 or U46619 could protect, without subsequent washing, against the antagonistic effect of benextramine. As shown in Fig. 2 , prior incubation of the tissues with neither SQ 30,741 (10 $\mu \mathrm{M}, 30 \mathrm{~min}$ ) nor $\mathrm{U} 46619(10 \mu \mathrm{M}$, incubated until a response plateau was achieved) produced any significant protection against the effect of subsequent exposure for 30 min to $100 \mu \mathrm{M}$ benextramine.

Treatment ( $30 \mathrm{~min}$ ) with $100 \mu \mathrm{M}$ benextramine had no

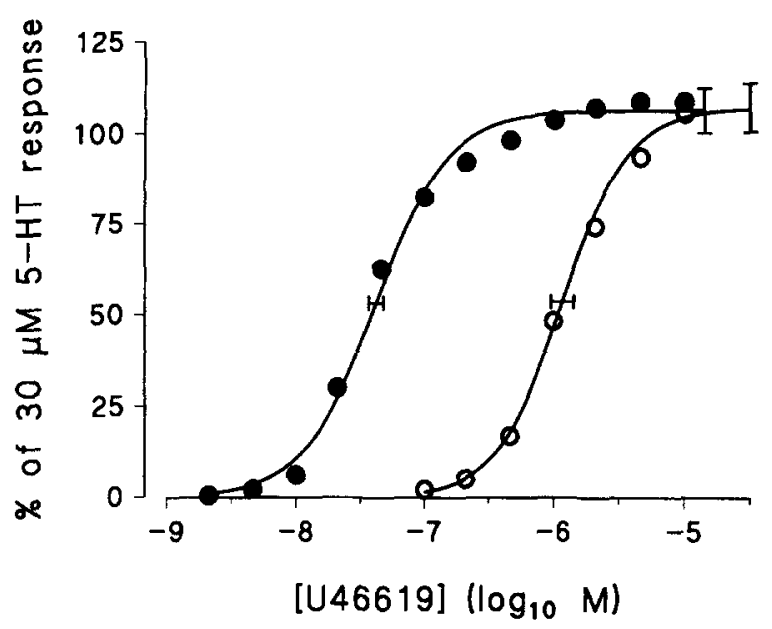

Fig. 1. Concentration-effect curves obtained with the rat isolated small mesenteric artery for $\mathrm{U} 46619$ in the absence $(O)$ and presence $(O)$ of 1 $\mu \mathrm{M}$ SQ 30,741 . The lines shown superimposed on the mean experimental data points $(n=5)$ were simulated using the Hill equation (see text for parameter estimates). Horizontal and vertical error (S.E.M.) bars are shown on the mean midpoint and upper asymptote locations, respectively. 


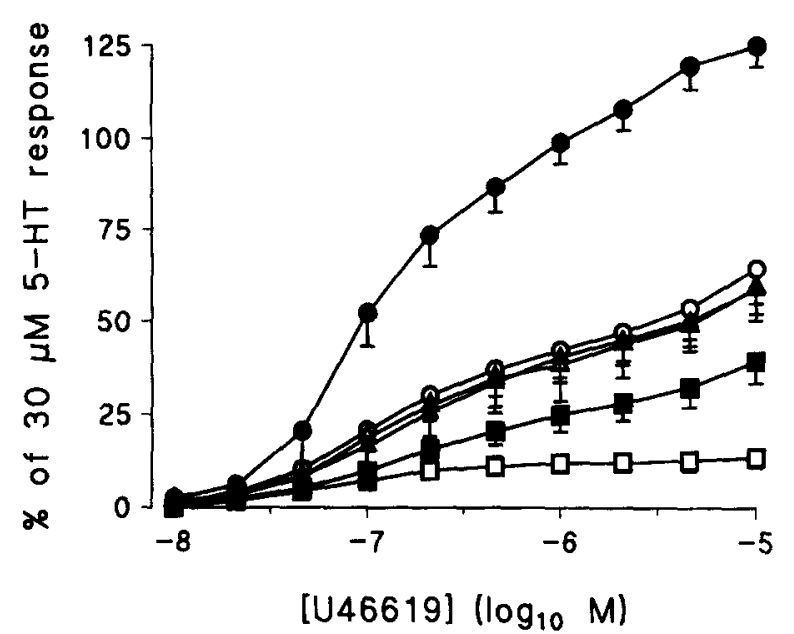

Fig. 2. Concentration-effect curves $(n=4-6)$ obtained with the rat isolated small mesenteric artery for U46619 following treatment with vehicle ( ), $100 \mu \mathrm{M}$ benextramine alone for $30(0), 60(\mathbb{D})$ and 120 $\min (\square)$ or $100 \mu \mathrm{M}$ benextramine for $30 \mathrm{~min}$ in the presence of $10 \mu \mathrm{M}$ SQ $30,741(\Delta)$ and $10 \mu \mathrm{M}(\Delta) \mathrm{U} 46619$. Error bars indicate S.E.M.

significant effect on the Hill equation parameter estimates $\left(\mathrm{p}[\mathrm{A}]_{50}: 8.98 \pm 0.14\right.$ and $8.91 \pm 0.09 ; n_{\mathrm{H}}: 2.6 \pm 0.6$ and $2.1 \pm 0.1 ; \alpha: 129 \pm 4 \%$ and $116 \pm 14 \%$ for control and benextramine-treated tissues, respectively, $n=3$ ) associated with the $E /[\mathrm{A}]$ curves of another contractile agent in this assay, arginine vasopressin $(0.1-100 \mathrm{nM})$. Thus, the antagonism of $U 46619$ by benextramine appeared not to be due to a nonspecific effect.

\section{Discussion}

In this study, we have investigated the effects of benextramine, a ligand previously classified and employed as an irreversible competitive antagonist of $\alpha$-adrenoceptors (Melchiorre, 1981) and neuropeptide $\mathrm{Y}$ receptors (Tessel et al., 1993; Palea et al., 1995), on the U46619-mediated contraction of the rat small mesenteric artery. Previous studies have shown that, in a variety of assays, U46619 mediates vasoconstriction via a selective action at prostanoid TP receptors (see Ogletree and Allen, 1992; Coleman et al., 1994; Baxter et al., 1995). This also appears to be the case in the rat isolated small mesenteric artery preparation, since the $\mathrm{pA}_{2}$ estimate of 7.4 obtained for SQ 30,741 was similar to previously reported affinity values for prostanoid TP receptors in various rat smooth muscle assays ( $\mathrm{p} K_{\mathrm{B}}$ : $\sim 7.8$; Ogletree and Allen, 1992) and human and monkey platelets $\left(\mathrm{p} K_{\mathrm{B}}: 7.1\right.$ and 7.2 , respectively; Schumacher et al., 1989).

Treatment of small mesenteric arteries with benextramine was found to produce significant inhibition of the response to U46619. The degree of this effect was time dependent, i.e. the longer the incubation with benextramine, the greater the magnitude of the antagonism, indicative of an irreversible antagonistic mechanism
(Furchgott, 1954, 1966; Palea et al., 1995). In an attempt to elucidate the underlying mechanism of the antagonistic effect of benextramine, we performed receptor protection experiments, since it would be expected that if an irreversible antagonist inhibits the response of an agonist by reducing the number of receptors, then a reversible competitive antagonist should be able to protect receptors from such inactivation (Furchgott, 1954, 1966). However, SQ 30,741 , in a concentration of $10 \mu \mathrm{M}$, which was $\sim 250$ times its apparent affinity for prostanoid TP receptors in the small mesenteric artery and thus would be expected to leave less than $0.5 \%$ of the receptors unoccupied, did not produce significant protection against the effects of benextramine treatment. Similarly, incubation with a near-maximally effective concentration ( $10 \mu \mathrm{M})$ of $\mathrm{U} 46619$ did not significantly inhibit the effects of benextramine. Hence, the protection experiments suggest that benextramine does not bind to the same site on the receptor as U46619 and SQ 30,741 , but acts as an irreversible noncompetitive antagonist (see Jenkinson et al., 1995) of the prostanoid TP receptor-mediated contraction of the rat small mesenteric artery. Therefore, benextramine cannot be used as a tool to determine dissociation equilibrium constants for agonists at prostanoid TP receptors in a manner similar to that described previously for $\alpha_{1}$-adrenoceptors (see, for example, Elliot and Pearce, 1994) and neuropeptide $\mathrm{Y} \mathrm{Y}_{1}$ receptors (Palea et al., 1995).

At present, we do not know the underlying mechanism of the antagonistic action of benextramine exposed in this study. The response to arginine vasopressin was not affected by benextramine, thus a nonspecific effect can be ruled out. Furthermore, vasopressin $V_{1}$ receptors, which are believed to mediate vasoconstriction to arginine vasopressin (Thibonnier, 1992), are coupled to the same signal transduction system as prostanoid TP receptors, namely the production of inositol-1,4,5-triphosphate $\left(\mathrm{IP}_{3}\right.$; Thibonnier, 1992; Coleman et al., 1994). This suggests that the antagonism was not due to a direct effect at the $\mathrm{IP}_{3}$ pathway.

Previously, it has been reported that benextramine is a blocker of calcium channels in rat brain with an associated $\mathrm{IC}_{50}$ value of $\sim 10 \mu \mathrm{M}$ (Plotek and Atlas, 1983). However, this effect was shown to be reversible (Plotek and Atlas, 1983) and thus cannot explain our data.

Overall, it remains to be clarified whether benextramine interferes with the effector pathway following prostanoid TP receptor activation by U46619 or whether it reduces agonist affinity and/or efficacy via an action at an allosteric receptor site.

\section{References}

Baxter, G.S., J.K. Clayton, R.A. Coleman, K. Marshall, R. Sangha and J. Senior, 1995, Characterization of the prostanoid receptors mediating constriction and relaxation of human isolated uterine artery, $\mathrm{Br} . \mathrm{J}$. Pharmacol. 116, 1692. 
Coleman, R.A., W.L. Smith and S. Narumiya, 1994, International Union of Pharmacology classification of prostanoid receptors: properties, distribution, and structure of the receptors and their subtypes, Pharmacol. Rev. 46, 205.

Elliot, S.R. and W.J. Pearce, 1994, Effects of maturation on $\alpha$-adrenergic receptor affinity and occupancy in small cerebral arteries, Am. J. Physiol. 267 (Heart Circ. Physiol. 36), H757.

Furchgott, R.F., 1954, Dibenamine blockade in strips of rabbit aorta and its use in differentiating receptors, J. Pharmacol. Exp. Ther. 111, 265.

Furchgott, R.F., 1966, The use of $\beta$-haloalkylamines in the differentiation of dissociation constants of receptor-agonist complexes, Adv. Drug Res. 3, 21

Jenkinson, D.H., E.A. Barnard, D. Hoyer, P.P.A. Humphrey, P. Leff and N.P. Shankley, 1995, International Union of Pharmacology Committee on Receptor Nomenclature and Drug Classification. IX. Recommendations on terms and symbols in quantitative pharmacology, Pharmacol. Rev. 47, 255.

Melchiorre, C., 1981, Tetramine disulfides: a new tool in $\alpha$-adrenergic pharmacology, Trends Pharmacol. Sci. 2, 209.

Mulvany, M.J. and W. Halpern, 1977, Contractile properties of small arterial resistance vessels in spontaneously hypertensive and normotensive rats, Circ. Res. 41, 19.

Ogletree, M.L. and G.T. Allen, 1992, Interspecies differences in thromboxane receptors: studies with thromboxane receptor antagonists in rat and guinea pig smooth muscles, J. Pharmacol. Exp. Ther. 260, 789.
Palea, S., M. Corsi, J.M. Rimland and D.G. Trist, 1995, Discrimination by benextramine between the NPY-Y, receptor subtypes present in rabbit isolated vas deferens and saphenous vein, Br. J. Pharmacol. 115,3 .

Plotek, Y. and D. Atlas, 1983, Characterization of benextramine as an irreversible $\alpha$-adrenergic blocker and as a blocker of potassiumactivated calcium channels, Eur. J. Biochem. 133, 539.

Schumacher, W.A., C.L. Heran, H.J. Goldenberg, D.N. Harris and M.L. Ogletree, 1989, Magnitude of thromboxane receptor antagonism necessary for antithrombotic activity in monkeys, Am. J. Physiol. 256 (Heart Circ. Physiol, 25), H726.

Tessel, R.E., D.W. Miller, G.A. Misse, X. Dong and M.B. Doughty, 1993, Characterization of vascular postsynaptic neuropeptide $Y$ receptor function and regulation. 1. NPY-induced constriction in isolated rat femoral artery rings is mediated by both $Y_{1}$ and $Y_{2}$ receptors: evidence from benextramine protection studies, J. Pharmacol. Exp. Ther. 265, 172.

Thibonnier, M., 1992, Signal transduction of $\mathrm{V}_{1}$-vascular vasopressin receptors, Regul. Pept. 38, 1.

Wang, Y., A. Mercer-Connolly, L. Lines, O. Toyoda and F. Coceani, 1994, Endothelium-denuded pulmonary resistance arteries from the fetal lamb: preparation and response to vasoactive agents, J. Pharmacol. Toxicol. Methods 32, 85 . 